\title{
Even Small Trade Costs Restore Efficiency in Tax Competition
}

\author{
Johannes Becker \\ Marco Runkel
}

CESIFO WORKING PAPER NO. 3221

CATEGORY 1: PUBLIC FINANCE

OCTOBER 2010

\footnotetext{
An electronic version of the paper may be downloaded

- from the SSRN website:

www.SSRN.com

- from the RePEc website:

- from the CESifo website: 


\title{
Even Small Trade Costs Restore Efficiency in Tax Competition
}

\begin{abstract}
We introduce transport cost of trade in products into the classical Zodrow and Mieszkowski (1986) model of capital tax competition. It turns out that even small levels of transport cost lead to a complete breakdown of the seminal result, the underprovision of public goods. Instead, there is a symmetric equilibrium with efficient public goods provision in all jurisdictions.
\end{abstract}

JEL-Code: H25, F23.

Keywords: tax competition, public goods provision, trade.

\author{
Johannes Becker \\ Institute of Public Economics 1 \\ University of Münster \\ Wilmergasse $6-8$ \\ 48143 Münster \\ Germany \\ johannes.becker@wiwi.uni-muenster.de
}

\author{
Marco Runkel \\ Faculty of Economics and Management \\ University of Magdeburg \\ P.O. Box 4120 \\ 39016 Magdeburg \\ Germany \\ marco.runkel@ovgu.de
}

This version: 14th October 2010

We thank Ron Davies, Clemens Fuest, Eckhard Janeba and Kai Konrad for helpful comments. The usual disclaimer applies. 


\section{Introduction}

Almost twenty-five years ago, the seminal contributions by Zodrow and Mieszkowski (1986) and Wilson (1986) set the starting point for a vast and still growing theoretical literature on capital tax competition. ${ }^{1}$ In this line of literature, tax competition is mainly interpreted as tax competition for mobile capital. Accordingly, the models focus almost entirely on factor markets for (mobile) capital and (immobile) labor or land. In the background, a perfectly competitive product market without any friction closes the model. ${ }^{2}$ However, one might argue that whereas perfect mobility of (financial) capital is a plausible assumption, zero cost of trading products between countries is not, except for some special cases.

In this short paper, we introduce transport cost of trade in products into the Zodrow and Mieszkowski (1986) model and derive the tax competition equilibrium. ${ }^{3}$ It turns out that the existence of transport cost leads to a complete breakdown of the main result, i.e. the underprovision of public goods. Instead, a symmetric equilibrium emerges in which all countries choose an efficient level of public goods provision. The rationale of this insight is that transport cost in the product sector imply that small differences in prices across countries do not give rise to international arbitrage. Since the balance of payments requires that trade in goods is accompanied by capital flows, imperfect arbitrage on the product market translates into a certain "stickiness" of capital. This allows governments to marginally adjust their capital tax rates until the efficient solution is reached. It is important to note that even small levels of transport cost suffice to switch from inefficiently low levels of public goods provision to efficiency. ${ }^{4}$

The remainder of the paper is organized as follows. Section 2 presents the basic model assumptions. In Section 3 we characterize the market equilibrium for given capital tax rates. Section 4 then turns to the equilibrium of the tax competition game between the countries. Section 5 briefly discusses the results and concludes.

\footnotetext{
${ }^{1}$ Literally hundreds of papers have since then explored the robustness of the results to various changes in the modelling approach and a great variety of extensions, many of which are surveyed in Wilson and Wildasin (2004) and Fuest et al. (2005).

${ }^{2}$ Zodrow and Mieszkowski (1986) do not mention the product market explicitly, whereas Wilson (1986) assumes the existence of two private consumption goods, a local one and a national one, the latter of which is costlessly tradable across regions.

${ }^{3}$ We focus on the basic framework introduced by Zodrow and Mieszkowski (1986), but our results concern the Wilson (1986) model as well. See footnote 14 for how our contribution relates to the analysis in Wilson (1987).

${ }^{4}$ Our argument is thus an application of the Diamond (1971) paradox. See Konrad (2010) for another application of this paradox to tax competition. He considers a model with firm mobility where firms face search costs, which arise because getting information on the true effective corporate tax rate is costly. This leads to a small, though decisive reduction in firm mobility and allows for an efficient tax competition equilibrium.
} 


\section{Setup}

We consider the Zodrow and Mieszkowski (1986) framework in the version presented by Hoyt (1991), ${ }^{5}$ and augment it by a transport sector. If transport costs are assumed to be zero, the model boils down to the original one.

There are $n \geq 2$ countries. As country indices we use $i, j \in\{1, \ldots, n\}$. Each country hosts a large number of perfectly competitive firms with mass of unity. The representative firm in country $i$ uses $k_{i}$ units of capital in order to produce a good according to the production function $F\left(k_{i}\right)$, which satisfies $F^{\prime}>0>F^{\prime \prime}$ and the Inada condition $\lim _{k_{i} \rightarrow 0} F^{\prime}\left(k_{i}\right)=\infty{ }^{6}$ Capital is rented at the world capital market at an interest rate of $r>0$. Denoting the price of the good produced in country $i$ by $p_{i}$ and the (source-based) capital tax rate set by country $i$ by $t_{i}>0$, the after-tax profits of the firm located in country $i$ are

$$
\pi_{i}=p_{i} F\left(k_{i}\right)-\left(r+t_{i}\right) k_{i}
$$

The first-order condition of profit maximization reads

$$
p_{i} F^{\prime}\left(k_{i}\right)-t_{i}=r
$$

This condition implies that the after-tax marginal return to capital, $p_{i} F\left(k_{i}\right)-t_{i}$, equals the interest rate $r$ and, thus, is equalized across countries.

Each country is populated by a large number of households which is, again, normalized to unity. The representative household in country $i$ derives utility from private consumption $c_{i}$ and publicly provided goods $g_{i}$ according to the utility function $u_{i}=U\left(c_{i}, g_{i}\right)$ with $U_{c}, U_{g}>0>U_{c c}, U_{g g}$. The household is endowed with savings of $\bar{k}$ which are invested at the world capital market. The household's income is given by interest income $r \bar{k}$ and after-tax firm profits $\pi_{i}$. This income is used to purchase $c_{i i}$ units of the consumption good from firms in country $i$ and $c_{i j}$ units of the consumption good from firms in country $j \neq i$. If purchased from firms in country $i$, the consumption good has a price of $p_{i}$. If purchased in country $j \neq i$, i.e. abroad, the price is $p_{j}$ and a transport cost $\tau \geq 0$ per unit of the good applies. The budget constraint of country $i$ 's household is

$$
r \bar{k}+\pi_{i}=p_{i} c_{i i}+\sum_{j \neq i}^{n}\left(p_{j}+\tau\right) c_{i j} .
$$

\footnotetext{
${ }^{5}$ While Hyot (1991) considers the general case with an arbitrary number of countries, Zodrow and Mieszkowski (1986) focus on the case of infinitesimally small countries which is obtained as special case of the Hyot (1991) model if the number of countries converges to infinity.

${ }^{6}$ We can replace the Inada condition by the weaker condition $F(0)=0$. This would leave our results completely unchanged, but comes at the cost of much more complicated proofs.
} 
Total consumption of the household in country $i$ equals the sum of consumption from all countries, i.e. $c_{i}=\sum_{j=1}^{n} c_{i j}$, where the units produced in different countries are perfect substitutes in consumption.

Each government has only one tax instrument, the unit tax on capital. Governments purchase private consumption goods and transform them into the publicly provided good on a one-to-one basis. The government in country $i$ purchases $g_{i i}$ units in its own country and $g_{i j}$ units in country $j \neq i$. Its budget constraint reads

$$
t_{i} k_{i}=p_{i} g_{i i}+\sum_{j \neq i}^{n}\left(p_{j}+\tau\right) g_{i j} .
$$

Total public consumption in country $i$ amounts to $g_{i}=\sum_{j=1}^{n} g_{i j}$.

Transport services are provided by a competitive sector which is exempt from corporate taxation and has a linear production function. The only input is capital. Shipping of one unit of the consumption good requires $\theta \geq 0$ units of capital including the original case of $\theta=0$. Profits of the transport sector are given by

$$
\pi^{\tau}=(\tau-\theta r) \sum_{i=1}^{n} \sum_{j \neq i}^{n}\left(c_{i j}+g_{i j}\right)
$$

Perfect competition reduces these profits to zero from which follows

$$
\tau=\theta r
$$

Zero profits and tax exemption imply that we neither need an assumption on to whom the transport firms belong nor on where they are located. ${ }^{7}$

Finally, the equilibrium condition for the world capital market reads

$$
\sum_{i=1}^{n}\left(k_{i}+\theta \sum_{j \neq i}^{n}\left(c_{i j}+g_{i j}\right)\right)=n \bar{k} .
$$

It equates the world capital demand of the production firms and the transport sector to the world capital supply of the households.

\footnotetext{
${ }^{7}$ Assuming that the transport sector is taxed actually does not change the main insights. However, such an assumption adds a number of complexities arising from the endogeneity of equilibrium transport costs and the necessity of assuming the location and ownership of transport firms.
} 


\section{Market Equilibrium}

In this section we analyze the equilibrium of private markets (capital, transport and product markets), taken as given the capital tax rates of the countries. As a benchmark, we first briefly consider the case without transport cost, in order to replicate the original result, and then turn to the case of positive transport cost.

Zero transport cost. Assume $\theta=0$ and, thus, $\tau=0$. According to the standard arbitrage argument, the price of the consumption good has then to be the same in all countries. Otherwise, all consumers purchase the good solely in the country with the lowest price, implying that demand in all other countries is zero. However, the Inada condition and (2) render supply in all countries positive and, thus, prevent such a market equilibrium. Normalizing the common price to unity we obtain ${ }^{8}$

$$
p_{i}=1 \text { for all } i
$$

Equations (2), (7) and (8) determine the capital allocation $\left\{k_{i}\right\}_{i=1}^{n}$, the product prices $\left\{p_{i}\right\}_{i=1}^{n}$ and the interest rate $r$ as functions of the tax rates $\left\{t_{i}\right\}_{i=1}^{n}$. Totally differentiating and following Zodrow and Mieszkowski (1986) in focusing on a symmetric situation with $t_{i}=t$ for all $i$, we obtain the comparative static results

$$
\begin{gathered}
\frac{\partial p_{j}}{\partial t_{i}}=0, \quad \frac{\partial r}{\partial t_{i}}=-\frac{1}{n}<0, \\
\frac{\partial k_{i}}{\partial t_{i}}=-(n-1) \frac{\partial k_{j}}{\partial t_{i}}=\frac{n-1}{n F^{\prime \prime}}<0, \quad j \neq i .
\end{gathered}
$$

These results show that, in the absence of transport cost, an increase in one country's capital tax rate drives out capital and, thus, increases the capital supply for all other countries. The resulting decline in the world interest rate increases capital demand and restores a new equilibrium. The reason is that capital is perfectly mobile, so changes in the capital tax rates immediately translate into changes in the user cost of capital and thereby induce capital movements. The relative prices of the consumption goods remain unchanged due to perfect arbitrage on the product market.

Positive transport cost. Assume $\theta>0$ and, thus, $\tau>0$. Let $p_{\ell}:=\min \left\{p_{i}\right\}_{i=1}^{n}$ and $p_{u}:=\max \left\{p_{i}\right\}_{i=1}^{n}$ denote the upper and lower bound of the price range of the consumption good. Then, there are at most three types of countries: countries

\footnotetext{
${ }^{8}$ The equilibrium condition for the common product market is $\sum_{i=1}^{n} \sum_{j=1}^{n}\left(c_{i j}+g_{i j}\right)=$ $\sum_{i=1}^{n} F\left(k_{i}\right)$. With the help of (1), (3) and (4) it is straightforward to show that this condition is always satisfied as identity, which reflects Walras' law in case of zero transport cost. Hence, we can follow Zodrow and Mieszkowski (1986) and ignore this equilibrium condition.
} 
with a price $p_{\ell}$, countries with a price in the interval $] p_{\ell}, p_{u}[$ and countries with a price $p_{u}$. The countries in the first and the last group are denoted as type $\ell$ and type $u$ countries, respectively. It can be ruled out that $p_{u}-p_{\ell}>\tau$, as this would imply that there is at least one type $u$ country with $p_{u}>p_{\ell}+\tau$, so the household and the government of this country purchase the consumption good only abroad and there is no demand for the good produced in this country. Again, such a situation cannot be a market equilibrium because the Inada condition and (2) render supply in type $u$ countries strictly positive. Hence, the arbitrage mechanism works whenever $p_{u}-p_{\ell}>\tau$ and reduces the price ranges to $p_{u}-p_{\ell} \leq \tau$.

In equilibrium we have either $p_{u}-p_{\ell}<\tau$ or $p_{u}-p_{\ell}=\tau$. Under $p_{u}-p_{\ell}<\tau$, households and governments in each country purchase the consumption good solely at home and there is no international trade in consumption goods. In contrast, if $p_{u}-p_{\ell}=\tau$, households and governments in type $u$ countries are indifferent between purchasing the good at home and purchasing it in type $\ell$ countries. In this case the consumption good may therefore be traded between countries. This, however, depends on the the tax rate differential between $t_{u}$ and $t_{\ell}$ as the following Lemma states.

Lemma Assuming positive transport cost $(\tau=\theta r>0)$ and a tax rate differential satisfying $t_{u}-t_{\ell} \leq \tau\left(r+t_{\ell}\right) / p_{\ell}>0$, the resulting market equilibrium implies $p_{u}-p_{\ell}<\tau$ and no trade in the consumption good.

Proof: The proof is by contradiction. Let the number of type $\ell$ and type $u$ countries be denoted by $n_{\ell}$ and $n_{u}$, respectively. If $p_{u}-p_{\ell}=\tau$, the household and government in a type $u$ country equally divide their consumption over their own country and all $n_{\ell}$ type $\ell$ countries. ${ }^{9}$ From (3) and (4), in each type $u$ country we obtain $c_{u u}=c_{u \ell}=\left[p_{u} F\left(k_{u}\right)+r\left(\bar{k}-k_{u}\right)-t_{u} k_{u}\right] /\left[p_{u}\left(1+n_{\ell}\right)\right]>0$ and $g_{u u}=$ $g_{u \ell}=t_{u} k_{u} /\left[p_{u}\left(1+n_{\ell}\right)\right]>0$. The household and government in a type $\ell$ country purchase the good solely at home, so $c_{\ell \ell}=\left[p_{\ell} F\left(k_{\ell}\right)+r\left(\bar{k}-k_{\ell}\right)-t_{\ell} k_{\ell}\right] / p_{\ell}>0$ and $g_{\ell \ell}=t_{\ell} k_{\ell} / p_{\ell}>0$. The product market equilibrium condition in a type $u$ country is $c_{u u}+g_{u u}=F\left(k_{u}\right)$. Inserting $c_{u u}$ and $g_{u u}$ and employing $c_{u u}=c_{u \ell}$ and $g_{u u}=g_{u \ell}$ yields $r\left(\bar{k}-k_{u}\right)=p_{u} n_{\ell}\left(c_{u \ell}+g_{u \ell}\right)>0$ and, thus, $k_{u}<\bar{k}$. The condition for the product market equilibrium in a type $\ell$ country reads $c_{\ell \ell}+g_{\ell \ell}+n_{u}\left(c_{u \ell}+g_{u \ell}\right)=F\left(k_{\ell}\right)$. Inserting now yields $r\left(\bar{k}-k_{\ell}\right)=-p_{\ell} n_{u}\left(c_{u \ell}+g_{u \ell}\right)<0$ and, thus, $k_{\ell}>\bar{k}$. From $F^{\prime \prime}<0$ and (2) follows that $k_{u}<\bar{k}<k_{\ell}$ is possible only if $F^{\prime}\left(k_{u}\right)>F^{\prime}\left(k_{\ell}\right)$ or $\left(r+t_{u}\right) / p_{u}>\left(r+t_{\ell}\right) / p_{\ell}$. The assumption $p_{u}=p_{\ell}+\tau$ then yields the contradiction $F^{\prime}\left(k_{u}\right) \leq F^{\prime}\left(k_{\ell}\right)$ if $t_{u}-t_{\ell} \leq \tau\left(r+t_{\ell}\right) / p_{\ell}$.

The intuition behind the Lemma is the following. With $p_{u}=p_{\ell}+\tau$, there are

\footnotetext{
${ }^{9}$ The results remain completely unchanged if we assume an unequal division of purchases.
} 
countries at the upper bound of the price range (type $u$ ) which purchase the good not only at home but also in countries at the lower bound of the price range (type $\ell$ ). The balance of payments then forces the high-price countries to export capital to the low-price countries. Hence, the marginal return to capital, $p_{i} F^{\prime}\left(k_{i}\right)$, is higher in high-price countries than in low-price countries. If tax rates in the two types of countries are equal, the after-tax marginal return to capital, $p_{i} F^{\prime}\left(k_{i}\right)-t$, is not equalized across countries, thereby violating (2) and preventing a market equilibrium. This argument remains true in the presence of positive, but not too large capital tax rates differentials, $t_{u}-t_{\ell} \leq \tau\left(r+t_{\ell}\right) / p_{\ell}>0$. Note that, in the absence of trade costs $(\tau=0)$, an equilibrium without trade only occurs if $t_{u}=t_{\ell}$, which is consistent with the Zodrow and Mieszkowski (1986) analysis.

In the next section, we follow Zodrow and Mieszkowski (1986) and focus on the symmetric tax competition equilibrium with $t_{i}=t$. Since this implies $t_{u}-t_{\ell}=0<$ $\tau\left(r+t_{\ell}\right) / p_{\ell}$, we can refer to the market equilibrium with $p_{u}-p_{\ell}<\tau$ and without trade. Under this condition, each household and each government purchases the consumption good solely at home, that is $c_{i i}, g_{i i}>0$ and $c_{i j}=g_{i j}=0$ for all $i, j$ and $j \neq i$. Then, the product market in country $i$ is in equilibrium if

$$
c_{i i}+g_{i i}=F\left(k_{i}\right)
$$

where (1), (3), (4) and $c_{i j}=g_{i j}=0$ for $j \neq i$ yield

$$
c_{i i}=F\left(k_{i}\right)+\frac{r\left(\bar{k}-k_{i}\right)-t_{i} k_{i}}{p_{i}}, \quad g_{i i}=\frac{t_{i} k_{i}}{p_{i}} .
$$

Inserting (12) into (11) gives $n$ equations which together with (2) for all $i$ and (7) with $c_{i j}=g_{i j}=0$ for $j \neq i$ determine the equilibrium capital allocation $\left\{k_{i}\right\}_{i=1}^{n}$, prices $\left\{p_{i}\right\}_{i=1}^{n}$ and interest rate $r$ as functions of the tax rates $\left\{t_{i}\right\}_{i=1}^{n} \cdot{ }^{10}$ Choosing the price in country 1 as numeraire, i.e. $p_{1}=1$, and totally differentiating yields

$$
\begin{aligned}
\frac{\partial p_{i}}{\partial t_{1}}=-\frac{\partial p_{i}}{\partial t_{i}}=-\frac{1}{F^{\prime}}, \quad \frac{\partial p_{i}}{\partial t_{j}}=0, \quad \frac{\partial r}{\partial t_{1}} & =-1, \quad \frac{\partial r}{\partial t_{i}}=0, \quad i, j \neq 1, \quad i \neq j \\
\frac{\partial k_{j}}{\partial t_{i}} & =0
\end{aligned}
$$

These comparative static results are diametral different from those in the absence of transport cost, compare (13) and (14) with (9) and (10). In particular, tax rate changes now do not affect the capital allocation, but alter the product prices. The intuition is that in the presence of positive transport cost the whole production

\footnotetext{
${ }^{10}$ Equations (11) and (12) imply that equation (7) is satisfied as identity. This is Walras' law in the presence of strictly positive transport cost.
} 
in a country is solely consumed by the household and government of this country. There is no trade in goods and, thus, the balance of payments requires that there is also no trade in capital, independent of the capital tax rates. ${ }^{11}$ Hence, the introduction of (even small) transport costs makes capital sticky and tax rate changes translate into price changes that maintain the market equilibrium.

\section{Tax Competition}

We now turn to the governments' choice of tax rates. Regardless of whether we have zero or positive transport cost, utility in country $i$ can be written as

$$
u_{i}=U\left[F\left(k_{i}\right)+\frac{r\left(\bar{k}-k_{i}\right)-t_{i} k_{i}}{p_{i}}, \frac{t_{i} k_{i}}{p_{i}}\right] .
$$

The government of country $i$ maximizes its residents' utility with respect to the tax rate $t_{i}$, taking as given the tax rates of the other countries $j \neq i$. The equilibrium of this Nash tax competition game is determined by the first-order condition

$$
\frac{\mathrm{d} u_{i}}{\mathrm{~d} t_{i}}=\frac{\partial u_{i}}{\partial t_{i}}+\frac{\partial u_{i}}{\partial r} \frac{\partial r}{\partial t_{i}}+\frac{\partial u_{i}}{\partial p_{i}} \frac{\partial p_{i}}{\partial t_{i}}+\frac{\partial u_{i}}{\partial k_{i}} \frac{\partial k_{i}}{\partial t_{i}}=0
$$

with

$$
\begin{gathered}
\frac{\partial u_{i}}{\partial t_{i}}=-\left(U_{c}-U_{g}\right) \frac{k_{i}}{p_{i}}, \quad \frac{\partial u_{i}}{\partial r}=U_{c} \frac{\bar{k}-k_{i}}{p_{i}}, \\
\frac{\partial u_{i}}{\partial p_{i}}=-U_{c} \frac{r\left(\bar{k}-k_{i}\right)-t_{i} k_{i}}{p_{i}^{2}}-U_{g} \frac{t_{i} k_{i}}{p_{i}^{2}}, \quad \frac{\partial u_{i}}{\partial k_{i}}=U_{g} \frac{t_{i}}{p_{i}}
\end{gathered}
$$

where in $\partial u_{i} / \partial k_{i}$ we have used the first-order condition (2).

Let us start by briefly replicating the result of Zodrow and Mieszkowski (1986). According to (8) and (9), without transport cost we have $p_{i}=1$ and $\partial p_{i} / \partial t_{i}=0$ for all $i$. Moreover, Zodrow and Mieszkowski (1986) focus on a symmetric tax competition equilibrium with $t_{i}=t$ for all $i$. Equations (2), (7) and $p_{i}=1$ then imply $k_{i}=\bar{k}$ in equilibrium. Inserting into (16)-(18) and rearranging yields

$$
\frac{U_{g}}{U_{c}}=\frac{1}{1-\varepsilon}>1
$$

where $\varepsilon:=-\left(\partial k_{i} / \partial t_{i}\right) t_{i} / k_{i}>0$ denotes the capital demand elasticity in country $i$ with respect to the tax rate in country $i$. In the absence of transport cost, this elasticity is strictly positive according to (10). Hence, equation (19) states that in the tax competition equilibrium the marginal rate of substitution between public

\footnotetext{
${ }^{11}$ Formally, equations (13) and (14) imply $k_{i}=\bar{k}$ independent of $t_{i}$.
} 
and private consumption, $U_{g} / U_{c}$, equals the marginal cost of public funds, $1 /(1-\varepsilon)$, and is thus larger than 1 which reflects the marginal rate of transformation between public and private consumption. This is the classical underprovision of public goods result obtained by the previous tax competition literature.

If we introduce (even small but) strictly positive transport cost, equations (11), (12) and (14) imply $k_{i}=\bar{k}$ and $\partial k_{i} / \partial t_{i}=0$ for all $i$. Inserting this together with (13) into (16)-(18) and rearranging yields

$$
\frac{U_{g}}{U_{c}}=1
$$

This condition implies symmetry with $t_{i}=t$ and $p_{i}=1$ for all $i .^{12}$ It states that the marginal rate of substitution equals the marginal rate of transformation between public and private consumption. Hence, we have proven the following

Proposition In the absence of transport cost $(\tau=\theta r=0)$, the symmetric tax competition equilibrium is characterized by equation (19) and, thus, ineffcient underprovision of public goods. In contrast, in the presence of transport $\operatorname{cost}(\tau=\theta r>0)$ there is a symmetric tax competition equilibrium with efficient public good provision characterized by equation (20).

Taking into account transport cost therefore restores efficiency in capital tax competition between countries. Whereas capital is perfectly mobile if transport costs are absent, capital becomes sticky in the presence of transport cost, at least in in a certain parameter range. Then, the use of capital taxes translates into consumer price adjustments and does not lead to capital movements. Under these circumstances, the individual government is able to increase the capital tax rate and, thus, public consumption until the efficient levels are attained.

\section{Discussion and Conclusion}

Our analysis shows that introducing even small transport cost to the product sector of the classical Zodrow and Mieszkowski (1986) model leads to a complete breakdown of the main result. The equilibrium switches from underprovision of public goods to efficiency. The reason is that even small imperfections on the trade side of the model translate into imperfect mobility of capital. In other words, transport cost in the product sector makes capital sticky. This allows governments

\footnotetext{
${ }^{12}$ In a more elaborated way, equation $(20)$ can be be written as $U_{g}\left[F(\bar{k})-t_{1} \bar{k}, t_{1} \bar{k}\right]=U_{c}[F(\bar{k})-$ $\left.t_{1} \bar{k}, t_{1} \bar{k}\right]$ for country 1 and $U_{g}\left[F(\bar{k})-t_{i} \bar{k} / p_{i}, t_{i} \bar{k} / p_{i}\right]=U_{c}\left[F(\bar{k})-t_{i} \bar{k} / p_{i}, t_{i} \bar{k} / p_{i}\right]$ for country $i \neq 1$. This implies $t_{1}=t_{i} / p_{i}$. Inserting into $F^{\prime}(\bar{k})-t_{1}=r=p_{i} F^{\prime}(\bar{k})-t_{i}$ yields $p_{i}=p_{1}=1$ and $t_{i}=t_{1}$ for $i \neq 1$. Hence, in the presence of transport cost symmetry is a result rather than an assumption as in the Zodrow and Mieszkowski (1986) framework.
} 
to costlessly increase their tax rate until the efficient solution is reached.

We are, of course, not the first ones to consider product market imperfections in the context of capital tax competition. It seems, though, that most contributors in the field being dissatisfied with the assumption of perfect product markets build their work on a different model class inspired by Black and Hoyt (1988) and, more recently, Melitz (2003). ${ }^{13}$ In these models, countries compete for imperfectly competitive firms and account for consumer price changes. Accounting for imperfect competition and firms comes at the price of giving up the focus on (financial) capital markets, though, and in many cases on general equilibrium effects.

What are the implications of our findings? A general lesson might be that product markets matter for the analysis of capital tax competition. ${ }^{14}$ Imperfections and distortions in this part of the economy may have severe repercussions on factor markets and, thus, on optimal capital tax policy. We certainly do not want to claim that, due to positive transport cost, there is no tax competition at all and the whole debate of the last twenty-five years was a chimaera. However, it seems that taking a closer look at the trade side of capital tax competition is worthwhile. While perfect capital mobility is a plausible assumption, zero transport cost for products is not. To sustain the classical result of inefficient public goods provision in the presence of transport cost, the model will have to be modified. A potential modification is the assumption of product heterogeneity, as in Melitz (2003) but by sticking to the assumption of a common financial capital market. We explore this approach in Becker and Runkel (2010).

\section{References}

[1] Becker, J. and Runkel, M. (2010). Capital Tax Competition and Trade, mimeo.

[2] Black, D.A. and Hoyt, W.H. (1989). Bidding for Firms, American Economic Review 79(5): 1249-1256.

[3] Davies, R., Eckel, C. (2010). Tax Competition for Heterogeneous Firms with Endogenous Entry. American Economic Journal: Economic Policy.

[4] Diamond, P. (1971). A Model of Price Adjustment, Journal of Economic Theory 3(2): 156-168.

\footnotetext{
${ }^{13}$ See Davies and Eckel (2010), Haufler and Stähler (2009) and the literature cited therein.

${ }^{14}$ This has also been the starting point of the analysis in Wilson (1987). He assumes a model with two goods and two factors. In equilibrium, countries specialize on the production of a single good which leads to a "wasteful diversity" in tax rate setting and public goods provision. In contrast to this study, our model sticks to the classical assumption of a product market with just one homogeneous good.
} 
[5] Fuest, C., B. Huber and J. Mintz (2005). Capital Mobility and Tax Competition - A Survey, Foundations and Trends in Microeconomics 1(1): 1-62.

[6] Haufler, A. and Stähler, F. (2009). Tax Competition in a Simple Model with Heterogeneous Firms: How Larger Markets Reduce Profit Taxes, CESifo Working Paper No. 2867.

[7] Hoyt, W.H. (1991). Property Taxation, Nash Equilibrium, and Market Power. Journal of Urban Economics 30(1): 123-131.

[8] Konrad, K.A. (2010). Search Costs and Corporate Income Tax Competition, mimeo.

[9] Melitz, M. J. (2003). The Impact of Trade on Intra-Industry Reallocations and Aggregate Industry Productivity, Econometrica 71(6): 1695-1725.

[10] Wilson, J. D. (1986). A Theory of Interregional Tax Competition, Journal of Urban Economics 19(2): 296-315.

[11] Wilson, J. D. (1987). Trade, Capital Mobility, and Tax Competition, Journal of Political Economy 95(4): 835-56.

[12] Wilson, J. D. and Wildasin, D.E. (2004). Capital Tax Competition: Bane or Boon?, Journal of Public Economics 88(6): 1065-91.

[13] Zodrow, G. R. and Mieszkowski, P. (1986). Pigou, Tiebout, Property Taxation, and the Underprovision of Local Public Goods, Journal of Urban Economics 19(3): 356-370. 


\section{CESifo Working Paper Series}

for full list see www.cesifo-group.org/wp

(address: Poschingerstr. 5, 81679 Munich, Germany, office@cesifo.de)

3156 Franziska Tausch, Jan Potters and Arno Riedl, Preferences for Redistribution and Pensions. What can we Learn from Experiments?, August 2010

3157 Martin Kolmar and Andreas Wagener, Inefficient Group Organization as Optimal Adaption to Dominant Environments, August 2010

3158 Kai Carstensen, Klaus Wohlrabe and Christina Ziegler, Predictive Ability of Business Cycle Indicators under Test: A Case Study for the Euro Area Industrial Production, August 2010

3159 Horst Rottmann and Timo Wollmershäuser, A Micro Data Approach to the Identification of Credit Crunches, August 2010

3160 Philip E. Graves, Appropriate Fiscal Policy over the Business Cycle: Proper Stimulus Policies Can Work, August 2010

3161 Michael Binder and Marcel Bluhm, On the Conditional Effects of IMF Program Participation on Output Growth, August 2010

3162 Michael Binder, Qianying Chen, and Xuan Zhang, On the Effects of Monetary Policy Shocks on Exchange Rates, August 2010

3163 Felix J. Bierbrauer, On the Optimality of Optimal Income Taxation, August 2010

3164 Nikolaus Wolf, Europe’s Great Depression - Coordination Failure after the First World War, September 2010

3165 Dan Kovenock and Brian Roberson, Conflicts with Multiple Battlefields, September 2010

3166 Jean-Pierre Ponssard and Catherine Thomas, Capacity Investment under Demand Uncertainty. An Empirical Study of the US Cement Industry, 1994-2006, September 2010

3167 Jørgen Juel Andersen, Jon H. Fiva and Gisle James Natvik, Voting when the Stakes are High, September 2010

3168 Michael Hoel, Is there a Green Paradox?, September 2010

3169 Scott Alan Carson, Nineteenth Century US African-American and White Female Statures: Insight from US Prison Records, September 2010

3170 Gil S. Epstein, Yosef Mealem and Shmuel Nitzan, Political Culture and Discrimination in Contests, September 2010 
3171 Sara Fisher Ellison, Jeffrey Greenbaum and Wallace P. Mullin, Diversity, Social Goods Provision, and Performance in the Firm, September 2010

3172 Silvia Dominguez-Martinez, Randolph Sloof and Ferdinand von Siemens, Monitoring your Friends, not your Foes: Strategic Ignorance and the Delegation of Real Authority, September 2010

3173 Marcus Dittrich and Beate Schirwitz, Union Membership and Employment Dynamics: A Note, September 2010

3174 Francesco Daveri, Paolo Manasse and Danila Serra, The Twin Effects of Globalization - Evidence from a Sample of Indian Manufacturing Firms, September 2010

3175 Florian Blöchl, Fabian J. Theis, Fernando Vega-Redondo and Eric O’N. Fisher, Which Sectors of a Modern Economy are most Central?, September 2010

3176 Dag Morten Dalen, Marilena Locatelli and Steinar Strøm, Longitudinal Analysis of Generic Substitution, September 2010

3177 Armin Falk, Stephan Meier and Christian Zehnder, Did we Overestimate the Role of Social Preferences? The Case of Self-Selected Student Samples, September 2010

3178 Christian Fahrholz and Cezary Wójcik, The Bail-Out! Positive Political Economics of Greek-type Crises in the EMU, September 2010

3179 Klaus Abberger and Wolfgang Nierhaus, The Ifo Business Cycle Clock: Circular Correlation with the Real GDP, September 2010

3180 Walter Krämer and Gerhard Arminger, “True Believers” or Numerical Terrorism at the Nuclear Power Plant, September 2010

3181 Bernard M.S. Van Praag, Dmitri Romanov and Ada Ferrer-i-Carbonell, Happiness and Financial Satisfaction in Israel. Effects of Religiosity, Ethnicity, and War, September 2010

3182 Dimitrios Koumparoulis and Paul De Grauwe, Public Capital, Employment and Productivity: An Empirical Investigation for Greece, September 2010

3183 John Whalley and Tanmaya Shekhar, The Rapidly Deepening India-China Economic Relationship, September 2010

3184 Andreas Schäfer and Thomas Steger, History, Expectations, and Public Policy: Economic Development in Eastern Germany, September 2010

3185 Thomas Eichner and Marco Runkel, Subsidizing Renewable Energy under Capital Mobility, September 2010

3186 Konstantinos Angelopoulos and James Malley, Fear of Model Misspecification and the Robustness Premium, September 2010 
3187 Philip E. Graves, A Note on the Design of Experiments Involving Public Goods, September 2010

3188 Glenn Ellison, How does the Market Use Citation Data? The Hirsch Index in Economics, September 2010

3189 Barbara Hanel and Regina T. Riphahn, The Employment of Mothers - Recent Developments and their Determinants in East and West Germany, September 2010

3190 Alexander Haupt and Silke Uebelmesser, Integration, Mobility, and Human Capital Formation, September 2010

3191 Vincenzo Galasso and Paola Profeta, When the State Mirrors the Family: The Design of Pension Systems, September 2010

3192 Stéphane Zuber and Geir B. Asheim, Justifying Social Discounting: The RankDiscounted Utilitarian Approach, September 2010

3193 Alexander Kemnitz, Educational Federalism and the Quality Effects of Tuition Fees, September 2010

3194 Claudia M. Buch, Sandra Eickmeier and Esteban Prieto, Macroeconomic Factors and Micro-Level Bank Risk, September 2010

3195 May Elsayyad and Kai A. Konrad, Fighting Multiple Tax Havens, September 2010

3196 Laszlo Goerke and Markus Pannenberg, Trade Union Membership and Dismissals, September 2010

3197 Ferdinand Mittermaier and Johannes Rincke, Do Countries Compensate Firms for International Wage Differentials?, September 2010

3198 John Boyd, Gianni De Nicoló and Abu M. Jalal, Bank Competition, Asset Allocations and Risk of Failure: An Empirical Investigation, September 2010

3199 Guido Heineck and Bernd Süssmuth, A Different Look at Lenin’s Legacy: Trust, Risk, Fairness and Cooperativeness in the two Germanies, September 2010

3200 Ingvild Almås, Tarjei Havnes and Magne Mogstad, Baby Booming Inequality? Demographic Change and Earnings Inequality in Norway, 1967-2000, October 2010

3201 Thomas Aronsson and Sören Blomquist, The Standard Deviation of Life-Length, Retirement Incentives, and Optimal Pension Design, October 2010

3202 Thorvaldur Gylfason and Eduard Hochreiter, Growing Together: Croatia and Latvia, October 2010

3203 Ken Burdett and Melvyn Coles, Tenure and Experience Effects on Wages: A Theory, October 2010 
3204 Wendy Carlin, Good Institutions are not enough: Ongoing Challenges of East German Development, October 2010

3205 Tobias König and Andreas Wagener, Tax Structure and Government Expenditures under Tax Equity Norms, October 2010

3206 Daniel W. Sacks, Betsey Stevenson and Justin Wolfers, Subjective Well-Being, Income, Economic Development and Growth, October 2010

3207 Mario Larch and Wolfgang Lechthaler, Why "Buy American” is a Bad Idea but Politicians still Like it, October 2010

3208 Guglielmo Maria Caporale and Luis A. Gil-Alana, US Disposable Personal Income and Housing Price Index: A Fractional Integration Analysis, October 2010

3209 Bruno S. Frey, Withering Academia?, October 2010

3210 Eva Mörk, Anna Sjögren and Helena Svaleryd, Childcare Costs and the Demand for Children - Evidence from a Nationwide Reform, October 2010

3211 Dan Kovenock, Brian Roberson and Roman M. Sheremeta, The Attack and Defense of Weakest-Link Networks, October 2010

3212 Shmuel Nitzan and Kaoru Ueda, Prize Sharing in Collective Contests, October 2010

3213 Erling Eide, Kristine von Simson and Steinar Strøm, Rank Dependent Utility, Tax Evasion and Labor Supply, October 2010

3214 Thomas Eichner and Marco Runkel, Interjurisdictional Spillovers, Decentralized Policymaking and the Elasticity of Capital Supply, October 2010

3215 Susan Athey and Glenn Ellison, Dynamics of Open Source Movements, October 2010

3216 Christian Bjørnskov, Axel Dreher, Justina A.V. Fischer and Jan Schnellenbach, Inequality and Happiness: When Perceived Social Mobility and Economic Reality do not Match, October 2010

3217 Thomas Cornelissen, Oliver Himmler and Tobias Koenig, Fairness Spillovers - The Case of Taxation, October 2010

3218 David E. Wildasin, State Corporation Income Taxation - An Economic Perspective on Nexus, October 2010

3219 Andreas Peichl, Nico Pestel and Hilmar Schneider, Does Size Matter? The Impact of Changes in Household Structure on Income Distribution in Germany, October 2010

3220 Alexander Kemnitz, A Simple Model of Health Insurance Competition, October 2010

3221 Johannes Becker and Marco Runkel, Even Small Trade Costs Restore Efficiency in Tax Competition, October 2010 